\title{
EFFECTS OF NITROGEN AND HERBICIDES ON ONION PRODUCTION IN A NEWLY RECLAIMED SOIL AND THEIR POTENTIAL HEALTH RISKS
}

\author{
Ahmed A. Abdelhafez ${ }^{1 *}$, Mohamed A.M. Ali ${ }^{2}$, Ahmed I. El-Tokhy \\ and Mohamed E. Amer ${ }^{4}$ \\ ${ }^{1}$ Department of Soils and Water, Faculty of Agriculture, Assiut Univ., \\ New Valley Branch, Egypt \\ ${ }^{2}$ Department of Horticulture, Faculty of Agriculture, Assiut Univ., \\ New Valley Branch, Egypt \\ ${ }^{3}$ Department of Plant Protections, Faculty of Agriculture, Assiut \\ Univ., New Valley Branch, Egypt \\ ${ }^{4}$ Central Lab. of Residue Analysis of Pesticides and Heavy Metals in \\ Food, Agricultural Research Center, Egypt \\ *E-mail: ahmed.aziz@ aun.edu.eg
}

itrogen addition and weeds controlling are important
practices for a successful plant growth and maximizing
yield. However, excessive nitrogen and herbicides application may pose a potential threat for soils, water and human health. This study was performed to investigate the effect of increasing nitrogen fertilization in combination with different weeds controlling practices on the growth and yield of onion $\mathrm{cv}$. Giza 6. Also, the potential risk due to residual nitrate and herbicides was a matter of concern. To achieve these goals, field experiments were performed for two successive growing seasons 2014/2015 and 2015/2016. Nitrogen fertilizer was added at different rates of $0.0,178.6,357.14$ and $535.71 \mathrm{~kg} \mathrm{~N} \mathrm{ha}^{-1}$. In addition, weeds were controlled through hand weeding and chemical herbicides addition. The obtained results showed that, increasing the rate of applied nitrogen in combination with hand weeding practice enhanced plant growth in terms of plant height, fresh weight, dry weight and bulbing ratio. Furthermore, nitrate levels in both soils and onion bulb increased due to high nitrogen addition. However, the levels of $\mathrm{P}$ and $\mathrm{K}$ in onion bulb decreased due to the increased biomass of the growing plants. For Hazard Index (HI) analysis, the HI of nitrate and bentazon didn't exceed the safe level of 1 . However, increasing the rate of applied nitrogen and using chemical herbicides elevated the values of HI. We concluded that, high nitrogen addition enhanced the plant growth and increased marketable yield, and there was no potential risk from nitrate. Therefore, additional studies are 
needed to investigate the feasibility of increasing nitrogen fertilization through foliar application and using hand weeding in the newly reclaimed soils to maximize yield and prevent the environment and human health deterioration.

Keywords: nitrogen, soil, nitrate, weed control, onion, risk assessment

The New Valley Governorate is located in the south-west of the Republic of Egypt and occupies the southern parts of the Western desert, representing about $56 \%$ of its area. Most of soils in the New Valley are newly reclaimed sand soils, characterized by their low organic matter and nutrients contents. Therefore, fertilizers addition is of great importance practice to overcome the infertility problem of such soils (FAO, 2000). Nitrogen is a major macro element required for successful plant growth (Brady and Weil, 2008). However, excessive nitrogen application may be lost through leaching to the ground water and surrounding environment and this increase intensifies the potential threat to the human health (Tamme et al., 2009 and Sharifi et al., 2011). In addition, nitrate accumulation in vegetable crops poses a potential threat for human health. Nitrate in its present form is non-toxic; however, about $5 \%$ of the ingested nitrate is converted to nitrite in saliva and the gastrointestinal tract, which is more toxic (Speijers, 1996; Mensinga et al., 2003 and Pannala et al., 2003). Onion is one of the most important commercial vegetable crops grown all over the world. In Egypt onion occupies about 11.88 thousand hectare with an average production of 233.1 thousand tons during the period of 2007-2014 (Hassan et al., 2014). Due to slow growth, shallow roots and lack of adequate foliage, onion crop cannot compete well with weeds. Therefore, weeds controlling practice is important to achieve high production of onion; especially, in the newly reclaimed soil with low fertility characteristics. Thus, the use of herbicides is a common practice to eliminate weeds growth (Ramalingam et al., 2013). Several types of herbicides are used extensively to combat weeds, leading to the contamination of crops by pesticide residues (Albero et al., 2001). Therefore, this study was performed to investigate the effect of high nitrogen fertilizer level in combination with different weeds management practices, i.e., hand weeding and conventional practice (using chemical herbicides) on the growth and yield of onion cv. Giza 6 in a newly reclaimed soil. In addition, the potential risk of residual nitrate and herbicides was also a matter of concern.

\section{MATERIALS AND METHODS}

\section{Description of the Study Site}

The experimental work was conducted at the agricultural farm of Faculty of Agriculture, Assiut University (the New Valley Branch) from

Egyptian J. Desert Res., 66, No. 1, 115-136 (2016) 
October to April of 2014/2015 and 2015/2016 growing seasons. The studied soils are virgin sand, characterized by low organic matter and nutrients contents; consequently, it had been subjected to reclamation since 2012 year.

\section{Experimental Procedure}

The experiment consisted of 12 treatments of combinations between four rates of nitrogen fertilizer, i.e., $0.0,178.60,357.14$ and $535.71 \mathrm{~kg} \mathrm{~N} \mathrm{ha}^{-1}$ (N0, N1, N2 and N3, respectively) and three levels of weeds controlling practices (un-weeded (P0), weeding with common herbicides by using bentazone + clethodium (P1) and hand weeding practice (P2). These treatments were arranged in a split plot system in a complete randomized block design with four replications. Nitrogen rates were the main plot, while weeding practices were the sub plots. Onion saplings (Allium cepa L.) cv. Giza 6 were planted in the study soils starting October 30, 2014 and 25, 2015. They were harvested early April 2015 and 2016.

\section{Fertilization}

Fertilization was adopted according to the recommendations of the Ministry of Agriculture, Egypt. For all treatments, $806.50 \mathrm{~kg}$ of ordinary super phosphate $\left(15.5 \% \mathrm{P}_{2} \mathrm{O}_{5}\right)$ equals to $125 \mathrm{~kg} \mathrm{P}^{-1}$ in combination with $119.05 \mathrm{~kg}$ of potassium sulphate (48\%) equals to $57.14 \mathrm{~kg} \mathrm{~K} \mathrm{ha}^{-1}$ were added to the soil. Ammonium nitrate $\left(\mathrm{NH}_{4} \mathrm{NO}_{3}\right)$ was used as a source of nitrogen fertilizer and was applied at rates of $0.0,533.14,1066.09$ and $1599.13 \mathrm{~kg}$ ha ${ }^{1}$ to achieve the rates of $0.0,178.6,357.14$ (recommended) and $535.71 \mathrm{~kg} \mathrm{~N}$ $\mathrm{ha}^{-1}$, respectively. The plot area was $30 \mathrm{~m}^{2}$; it contains five lines with 10 length and $0.6 \mathrm{~m}$ distance between two lines. Nitrogen fertilizer was divided into equal four application portions; these additions started after 15 days from transplanting and repeated three times 15 days intervals as soil application.

\section{Weeds Controlling Practices}

\subsection{Un-amended treatment (un-weeded)}

In this treatment both narrow and broad leaf weeds were allowed to grow freely without any treatment.

\subsection{Conventional herbicides treatment}

This program intended only herbicide treatments at the recommended rate of application i.e., $1.19 \mathrm{~L}$ of basagran mixed with $238 \mathrm{~L}$ of water and sprayed for a hectare to combat broadleaf weeds. Basagran is a common herbicide containing bentazon as an active ingredient with a chemical formula of (3-isopropyl-1H-2,1,3-benzothiadiazin-4(3H)-one 2,2-dioxide. For narrow leaves, clethodium with a chemical formula of (2-\{(E)-1-[(E)-3chloroallyloxyimino] propyl\}-5-[2-(ethylthio) propyl]-3-hydroxycyclohex-2enone) as an effective ingredient was sprayed at a rate of $0.595 \mathrm{~L}$ per $238 \mathrm{~L}$ water for a hectare. Herbicides applications began after 20 days of 
transplanting followed by two applications 30 days for each. Herbicides were foliar sprayed on the plants by using an automatic sprayer.

\section{Hand Weeding Practice}

This program intended only hand weeding as a common practice for cultural control of Integrated Pest Management (IPM). The practice was performed twice per month. The treatment was adopted continuously for five months.

\section{Soil Analysis}

Surface soil samples $(0-15 \mathrm{~cm})$ were collected from each treatment 3 times with an average sampling period of 2 months, air dried, sieved to pass through a $2 \mathrm{~mm}$ sieve, and then used for further analyses. The particle size distribution was determined using the pipette method as described by Akoto et al. (2008). Soil reaction (pH) and electrical conductivity (EC) were determined in 1:1 soil to water suspensions and supernatants, respectively, using the method described by Jones (2001). Total organic carbon content was determined using Welkley-Black procedure (Nelson and Sommers, 1996). Physical and chemical properties of the soil are shown in table (1). Nitrate $\mathrm{NO}_{3}{ }^{-}$was determined by using the method described by Doane and Horwa'th (2003). Briefly, $10 \mathrm{~g}$ of fresh soil was extracted with $50 \mathrm{ml}$ of $2 \mathrm{M}$ $\mathrm{KCl}$ and filtered. The reagent was prepared as follows: a $0.5 \mathrm{~g}$ vanadium (III) chloride $\left(\mathrm{VCl}_{3}\right)$ was dissolved into $200 \mathrm{ml}$ of $0.5 \mathrm{M} \mathrm{HCl}$. A $200 \mathrm{mg}$ portion of sulfanilamide and $10 \mathrm{mg} \mathrm{N}$-(1-naphthyl) ethylenediamine dihydrochloride (NEDD) were added. Thereafter, $1 \mathrm{ml}$ of sample was mixed thoroughly with $0.80 \mathrm{ml}$ reagent and left for color development at room temperature. Then absorbance was measured at $540 \mathrm{~nm}$. Total nitrogen was measured by the modified micro-kjeldahl apparatus of Parnars and Wagner as described by Jones et al. (1991).

\section{Plant Analysis}

\subsection{Vegetative Growth Characters and Yield}

Plant height was measured one month prior to the harvest stage. Briefly, the average height of 10 plant samples from each plot was measured (cm) from soil surface to the longest leaf blade of the plant. The vegetative parts (bulb and leaves) of chosen plants for each plot were weighed directly to determine the fresh weight $(\mathrm{g})$. Thereafter, plants were oven dried at $70^{\circ} \mathrm{C}$ for approximately two days (till constant weight was attained), and the dry weight was recorded. Bulbing ratio was calculated by dividing neck diameter by bulb diameter (Mann, 1952). At harvesting date (the first week in April in both seasons), all onion plants of each plot were harvested and cured for 15 days after harvest. The harvested bulbs were separated to marketable and non-marketable yield. Briefly, bulbs with single, homogenized and without any distortions were classified as marketable

Egyptian J. Desert Res., 66, No. 1, 115-136 (2016) 
yield, while bulbs which doubles, bolters, pickles, un-homogenized and with any distortions were classified as non-marketable yield. Marketable and nonmarketable yield were weighed $\left(\mathrm{kg} \mathrm{plot}^{-1}\right)$ and converted into ton ha ${ }^{-1}$.

\subsection{Chemical analysis}

Plant samples were collected after 2 months, 4 months from transplanting and at the harvest stage; thereafter, plants were washed with tap water several times then deionized water, and the plant materials were oven dried at $70^{\circ} \mathrm{C}$ for approximately $48 \mathrm{~h}$. Approximately $0.2 \mathrm{~g}$ portion of the dried material was subjected to digestion with a mixture of concentrated sulfuric acid $(10 \mathrm{ml})$ and perchloric acid $(2 \mathrm{ml})$. Total nitrogen was measured by the modified micro-kjeldahl apparatus of Parnars and Wagner as described by Jones et al. (1991). Phosphorus and K were measured by spectrophotometer and flame photometer instruments, respectively. For $\mathrm{NO}_{3}$ determination, fresh samples of onion bulbs were cut into small pieces and placed into a $50 \mathrm{ml}$ falcon tube and $30 \mathrm{ml}$ portion of distilled water was added, and then subjected for boiling for 10 minutes. Thereafter, samples were allowed to pass through a 41 Whatman filter paper, and the volume was completed to $50 \mathrm{ml}$. The concentration of $\mathrm{NO}_{3}{ }^{-}$was measured following the aforementioned description of Doane and Horwa'th (2003).

Table (1).Physicochemical characteristics of the study soil.

\begin{tabular}{|c|c|c|c|c|c|c|c|c|c|c|c|c|}
\hline \multirow{3}{*}{${ }^{*} \mathrm{pH}$} & \multirow{3}{*}{$\begin{array}{c}\mathrm{EC}, \\
\left(\mathrm{dS} \mathrm{m}^{-1}\right)\end{array}$} & \multirow{3}{*}{$\begin{array}{l}\stackrel{+}{0 \mathrm{M},} \\
\left(\mathrm{g} \mathrm{kg}^{-1}\right)\end{array}$} & \multicolumn{6}{|c|}{ Nutrient content, mg kg-1 } & \multirow{2}{*}{\multicolumn{3}{|c|}{ Particle size distribution, \% }} & \multirow{3}{*}{$\begin{array}{c}\text { Textural } \\
\text { class }\end{array}$} \\
\hline & & & \multicolumn{2}{|l|}{$\mathrm{N}$} & \multicolumn{2}{|l|}{$\mathbf{P}$} & \multicolumn{2}{|l|}{$\mathrm{K}$} & & & & \\
\hline & & & Total & Available & Total & Available & Total & Available & Clay & Silt & Sand & \\
\hline $7.97 \pm$ & $026+004$ & $1.10 \pm$ & 159.60 & $2070+245$ & $6030+67$ & $466+000$ & $243.00 \pm$ & $154.00=$ & $6.84 \pm$ & $11.24 \pm$ & $81.92 \pm$ & Sond \\
\hline 0.06 & $0.200 .0 .0 t$ & 0.2 & \pm 11.30 & $29.200=2.45$ & $0.200-0.14$ & $+.00=0.92$ & 13.23 & 8.76 & 0.48 & 0.47 & 0.31 & S talu \\
\hline
\end{tabular}

${ }_{\mathrm{pH}}^{\mathrm{p}}$ determined in 1:1 soil: water mixture

${ }^{\dagger} \mathrm{EC}$, detemined in 1:1 soil: water mixture

$\ddagger 0 \mathrm{M}$, organic matter

\section{Herbicides Analysis}

An LC-MS/MS was performed with an Agilent 1200 Series HPLC instrument coupled to an API 4000 Qtrap MS/MS from Applied Biosystems with an electrospray ionisation (ESI) interface. Separation was performed on an Agilent ZORBAX Eclipse XDB C18 column 4.6 x $150 \mathrm{~mm}, 5$ micron particle size. Centrifuge (Heraues up to $4000 \mathrm{rpm}$ ). PFTE or polyethylene 15 $\mathrm{ml}$ and $50 \mathrm{ml}$ with screw cap tubes. Ten grams plant sample were weighed in $50 \mathrm{ml}$ PFTE tube, $10 \mathrm{ml}$ acetonitrile was added and was shaken for one minute. The buffer-salt-mixture was added and was shaken immediately for one minute. The sample was centrifuged at $4000 \mathrm{rpm}$ for 5 minutes. Portion 
of acetonitrile layer was filtrated using syringe filter and directly injected into LC-MS/MS system using ESI positive and negative mood. Stock solution: $1000 \mu \mathrm{g} \mathrm{m} \mathrm{L}^{-1}$ reference standard solution of each herbicide were prepared in methanol. Separation was performed on a C18 column ZORBAX Eclipse XDB-C18 $4.6 \times 150 \mathrm{~mm}, 5 \mu \mathrm{m}$ particle size. The injection volume was $5 \mu \mathrm{l}$. A gradient elution program at $0.3 \mathrm{ml} \mathrm{min}^{-1}$ flow, in which one reservoir contained $10 \mathrm{mM}$ ammonium formate solution in methanolwater (1: 9) and the other contained methanol was used. The ESI source was used in the positive and negative mode, and N2 nebulizer, curtain, and other gas settings were optimized according to recommendations made by the manufacturer; source temperature was $400^{\circ} \mathrm{C}$, ion spray potential, $5500 \mathrm{~V}$, declustering potential and collision energy were optimized using a Harvard apparatus syringe pump by introducing individual herbicide solutions into the MS instrument to allow optimization of the MS/MS conditions. The determination of residual clethodium and bentazon was performed following the description of Anastassiades et al. (2003).

\section{Weed Density}

The weed count was recorded species-wise using $0.5 \mathrm{~m} \times 0.5 \mathrm{~m}$ quadrat from four randomly fixed places in each plot and the weeds falling within the frames of the quadrat were counted, recorded and the mean values were expressed in number $\mathrm{m}^{-2}$ (Ramalingam et al., 2013).

\section{Statistical Analysis}

The obtained results were statistically analyzed using a SAS package (ver. 9.1). Means of four replicates for all analyses were subjected to oneway ANOVA. Tukey's significant difference (HSD) studentised range test was applied for significant differences among means $(p<0.05)$. Pearson's correlation coefficients were also performed among various parameters.

\section{Human Health Aspects}

Hazard evaluation of human health was assessed to determine the level of exposure to nitrate $\mathrm{NO}_{3}{ }^{-}$and the residual herbicides effect on people living in the area via direct ingestion of contaminated onion bulb. The noncarcinogenic contaminants exposure rates (chronic exposure rates) were calculated according to the following equations (USEPA, 1997; Lee et al., 2006 and Zheng et al., 2010):

$$
\mathrm{ADD} \text { of fresh onion ingestion }=\frac{\mathrm{C} \times \mathrm{IR} \times \mathrm{ED} \times \mathrm{EF}}{\mathrm{BW} \times \mathrm{AT}}
$$

Where ADD is the average daily dose of specific contaminants, $\mathrm{C}$ the metal concentration of media (fresh bulb mg kg kg $^{-1}$, IR the ingestion rate per unit time, ED the exposure duration, EF the exposure frequency, BW the humans body weight, AT the averaging time. The parameters in the ADD formulas and the toxicity indices of the nitrate and studied herbicides are presented in 
table 2. The obtained ADD values were used to determine the hazard index (HI) as follows (Abdelhafez et al., 2012; 2015 and Abdelhafez and Li, 2015):

$$
H I=\frac{A D D}{R f D}
$$

where RfD is the reference dose which is defined as the maximum daily intake of contaminant without deleterious effects (Abdelhafez et al., 2012, 2015 and Abdelhafez and Li, 2015).

Table (2). Human and toxicity parameters used to characterize the Average Daily Dose (ADD) and Hazard Index (HI) values of onion bulbs.

\begin{tabular}{|c|c|c|c|}
\hline Parameter & Description & Value & Unit \\
\hline $\mathrm{C}$ & Contamination level & -- & $\mathrm{mg} \mathrm{kg}^{-1}$ \\
\hline IR & $\begin{array}{l}\text { Ingestion rate per } \\
\text { unit time }\end{array}$ & 123.29 & $\mathrm{~g} \mathrm{day}^{-1}$ \\
\hline $\mathrm{EF}$ & Exposure frequency & 365 & days year ${ }^{-1}$ \\
\hline ED & Exposure duration & 60 & years \\
\hline BW & Body weight & 70 & $\mathrm{~kg}$ \\
\hline AT & Average time & $30 \times 365$ & days \\
\hline $\begin{array}{l}\text { Toxicity } \\
\text { parameters }\end{array}$ & $\mathrm{NO}_{3}^{-}$ & Bentazon & Clethodium \\
\hline $\begin{array}{l}\text { RfD, } \mathrm{mg} \mathrm{kg}^{-1} \\
(\mathrm{BW})\end{array}$ & 3.7 & $0.03 *$ & $0.01 * *$ \\
\hline $\operatorname{MRL}\left(\mathrm{mg} \mathrm{kg}^{-1}\right)$ & -- & $0.04 * *$ & $0.5^{* *}$ \\
\hline
\end{tabular}

RfD reference dose

MRL maximum residual level

* USEPA (1997).

**Data obtained from (FAO/WHO (1995), EU Scientific Committee for Food (EU Scientific Committee, 1995).

\section{RESULTS AND DISCUSSION}

\section{Description of the Studied Soil}

As shown in table (1), the soil had a sand texture, and the sand fraction was dominant with an average value of $81.92 \%$. The $\mathrm{pH}$ value of the studied soil was 7.97 with averages electrical conductivity (EC) and OM values of $0.26 \mathrm{dS} \mathrm{m}^{-1}$ and $1.10 \mathrm{~g} \mathrm{~kg}^{-1}$. The soil is very poor in its $\mathrm{N}$ and $\mathrm{P}$ contents; however, relative amounts of $\mathrm{K}$ are present due to the spread of glauconite and mica minerals in the soils of the New Valley (personal observation). In addition, the organic matter content of the soil is very low due to the high oxidation rates of organic matter because of the high temperature and low addition of organic matter into the soil. 


\section{Chemical Changes in Soil as Affected by Nitrogen Rates and Weeds Controlling Practices}

Nitrogen fertilizer had been added with different rates below and higher the recommendation of the Ministry of Agricultural, Egypt. Ammonium nitrate fertilizer with an average nitrogen content of $33.5 \% \mathrm{~N}$ was added to the studied soil. Soil samples were collected 3 times at a constant time interval ( 2 months). The obtained results showed that soil chemical characteristics didn't change significantly during the growing seasons of 2014/2015 and 2015/2016. Soil pH didn't change significantly due to the buffering effect of the soil. Generally, weeds controlling practices had no effects on soil $\mathrm{pH}$. The average $\mathrm{pH}$ values were 7.99, 7.78, 8.12 and 8.20 for N0, N1, N2 and N3 treatments, respectively, during the first two sampling times. However, the soil $\mathrm{pH}$ has changed to $8.28,8.22,8.25$ and 8.34 for the above mentioned treatments, respectively. This could be attributed to the physiological effect of ammonium nitrate fertilizer. Soil electrical conductivity (EC) showed a different trend, the average EC values of the studied treatments were $0.30,0.34,0.40$ and $0.56 \mathrm{dS} \mathrm{m}^{-1}$ for N0, N1, $\mathrm{N} 2$ and N3, respectively, during the first two sampling times. Thereafter, the EC values tended to increase to reach $0.49,0.62,0.65$ and $0.70 \mathrm{dS} \mathrm{m}^{-1}$ after 6 months of retranslating. This could be attributed to complete addition and dissolving of the applied mineral fertilizer on one hand, and the dissolved salts applied to the soil upon application of the irrigation water, on the other hand. For nitrate accumulation in soil, the obtained results showed that the levels of nitrate accumulation in soil correlated significantly $(p<0.01)$ with the level of $\mathrm{N}$ application and sampling time (Fig. 1). The highest $\mathrm{NO}_{3}{ }^{-}$ concentrations were found after 4 months of retranslating of onion for all treatments (the final addition of nitrogen fertilizer). In addition, the highest $\mathrm{NO}_{3}{ }^{-}$concentrations were found due to the highest application rate of nitrogen $(\mathrm{N} 3)$ regardless of weed controlling practices. The average $\mathrm{NO}_{3}{ }^{-}$ concentration due to the $\mathrm{N} 3$ treatment was $177.66 \mathrm{mg} \mathrm{kg}^{-1}$ followed by $\mathrm{N} 2$ and $\mathrm{N} 1$ treatments with average $\mathrm{NO}_{3}{ }^{-}$concentrations of 126.77 and $70.58 \mathrm{mg}$ $\mathrm{kg}^{-1}$, respectively, to lesser extent of $\mathrm{NO}$ treatment with average $\mathrm{NO}_{3}{ }^{-}$ concentration of $19.41 \mathrm{mg} \mathrm{kg}$. Thereafter, the levels of $\mathrm{NO}_{3}^{-}$in soil decreased after 6 months of retranslating by $11.34 \%$ and $29.76 \%$ for N3P2 and NOP1, respectively. It can be expected that the potential risk might increase due to leaching of $\mathrm{NO}_{3}{ }^{-}$through drained water to the ground water and surrounding environment by increasing the rate of applied nitrogen fertilizer. Nitrate is a major contaminant for ground and surface water, and may cause a serious risk for human and the environment (Xie and Zhu, 2003; Chen et al., 2005 and Dragon, 2013). Once nitrogen fertilizers are added to the soils, the growing plants absorb the nitrogen in different forms, i.e., $\mathrm{NO}_{3}^{-}, \mathrm{NO}_{2}^{--}$and/or $\mathrm{NH}_{4}^{+}$. However, the excessive addition of nitrogen over the requirement of the growing plants is subjected to a considerable loss

Egyptian J. Desert Res., 66, No. 1, 115-136 (2016) 
by different routes, i.e., leaching, volatilization and denitrification (Brady and Weil, 2008 and Tamme et al., 2009). Therefore, excessive applications of $\mathrm{N}$ fertilizer to the soil can cause $\mathrm{NO}_{3}{ }^{-}$contamination of groundwater, resulting in further environmental and health damage; since the major source of water for different utilizations, i.e., drinking, agricultural and industrial purposes in the New Valley is the ground water.

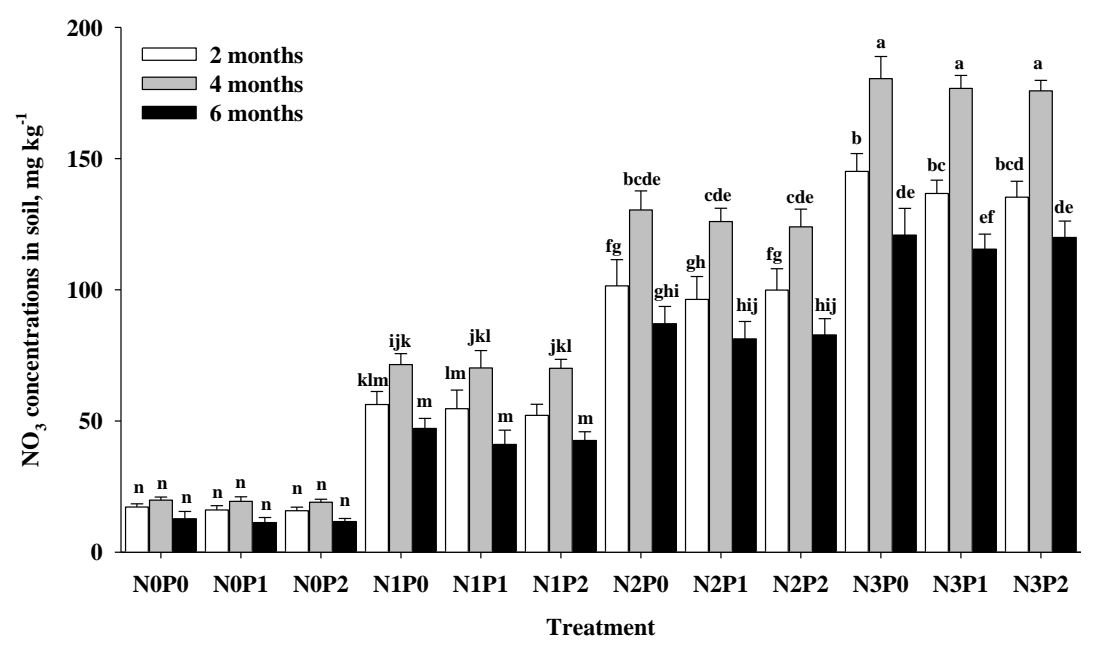

Fig. (1). Average nitrate concentrations in soils as affected by nitrogen fertilization rate and weeds controlling practices.

Means with the same letter within a column are not significantly different at $p<0.05$.

\section{Vegetative Growth Characters and Yield}

Data presented in table (3) show the effect of nitrogen fertilization rates on onion growth parameter and yield under different weeds controlling practices. Generally, the growing plants in the second season showed a slight increment in vegetative growth due to the accumulation trend of added mineral fertilizers. Increasing the rate of $\mathrm{N}$ fertilizer application in combination with hand weeding practice led to the enhancement of plant growth parameters in terms of plant height, fresh weight, dry weight and bulbing ratio. In addition, both fresh and dry weights and bulbing ratio of onion plant increased significantly due to increasing nitrogen fertilization and the use of hand weeding practice. The onion yield was divided into the marketable and non-marketable yield. The obtained results showed that increasing the rate of applied nitrogen fertilizer in addition to hand weeding practice led to increase the marketable yield of onion. Halvorson et al. (2006) went almost to a similar finding where they found that increasing the 


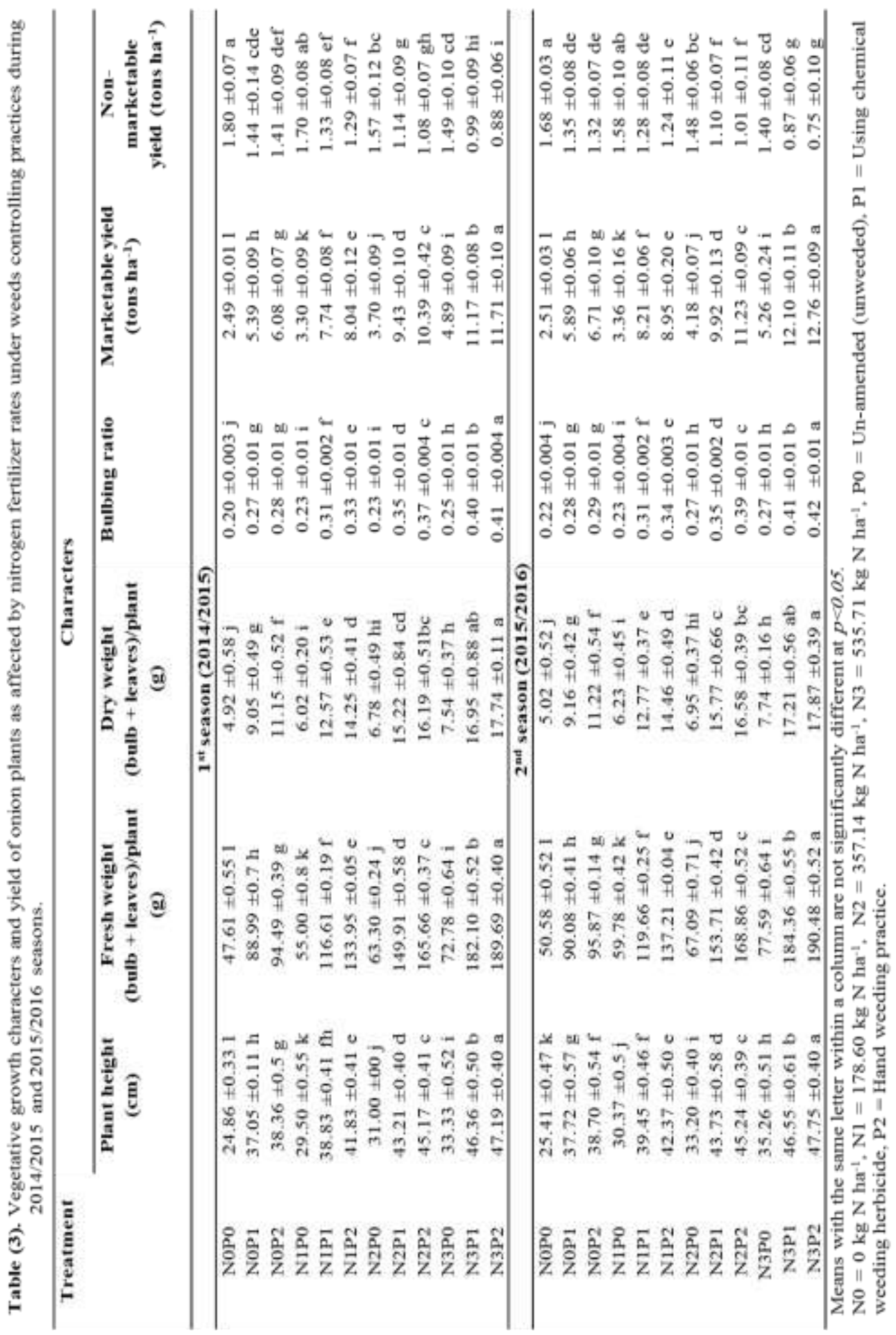

Egyptian J. Desert Res., 66, No. 1, 115-136 (2016) 
rate of nitrogen fertilizer maximized marketable fresh onion yield. On the other hand, the lowest rate of nitrogen fertilizer recorded the highest nonmarketable yield of onion. The enhancement of vegetative growth and yield could be attributed to the increased levels of nitrogen and the use of hand weeding practice. These results are in agreement with the previous studies of Buckland et al. (2013), who showed that increasing the rate of applied nitrogen fertilizers led to enhance the vegetation growth and yield of onion. Similarly, Katung et al. (2005) found that higher dose of nitrogen increased marketable yield of onion (10 $\left.\mathrm{Mg} \mathrm{ha}^{-1}\right)$ compared to control treatment. El-Desuki et al. (2006) showed that total bulbs yield, marketable yield, non-marketable yield and bulb quality were gradually increased with increasing level of NPK fertilizers from 40, 70 up to $100 \%$ of the recommended doses. Total marketable fresh onion yield increased with increasing nitrogen rate from 0 to $224 \mathrm{~kg} \mathrm{~N} \mathrm{ha}^{-1}$ (Halvorson et al., 2007). Nitrogen is the major macro nutrient and plays an important role for improving color, vigor of the leaf canopy and meristematic activity, which contributes to the increase in number of cells and cell elongation, consequently increasing the vegetative growth and yield of crops (Sangeetha and Singaram, 2007; Zhou et al., 2011 and Geries, 2013).

\section{N, P and K Contents in Onion Leaves and Bulb}

Generally, increasing the rate of applied nitrogen fertilizer increased the average nitrogen contents in both leaves and bulb (Table 4). In addition, the adoption of hand weeding practice for controlling weeds growth significantly enhanced the growing plant for nutrients uptake compared to control (untreated) and conventional treatment of weeds by using chemical herbicides. The average $\mathrm{N}$ contents in leaves and bulb were 1.34 and $1.20 \%$, respectively, for control treatment without nitrogen applications and weeds controlling practices. However, the average $\mathrm{N}$ contents significantly increased by increasing the rate of applied nitrogen fertilizer; especially in combination with hand weeding practice. Nasreen et al. (2007) found that nitrogen uptake by onion bulbs increased progressively with increasing nitrogen application up to $120 \mathrm{~kg} \mathrm{ha}^{-1}$. Halvorson et al. (2008) went almost to similar finding; they have found that nitrogen contents in onion leaves increased with high nitrogen application $\left(224 \mathrm{~kg} \mathrm{ha}^{-1}\right)$. Significantly the lowest $\mathrm{N}$ uptake was noted in onion bulb with $0 \mathrm{~kg} \mathrm{~N} \mathrm{ha}^{-1}$. In contrast, $\mathrm{P}$ and $\mathrm{K}$ concentrations decreased in leaves and bulb due to increasing the rate of applied nitrogen fertilizer N2 and N3, respectively. This could be attributed 


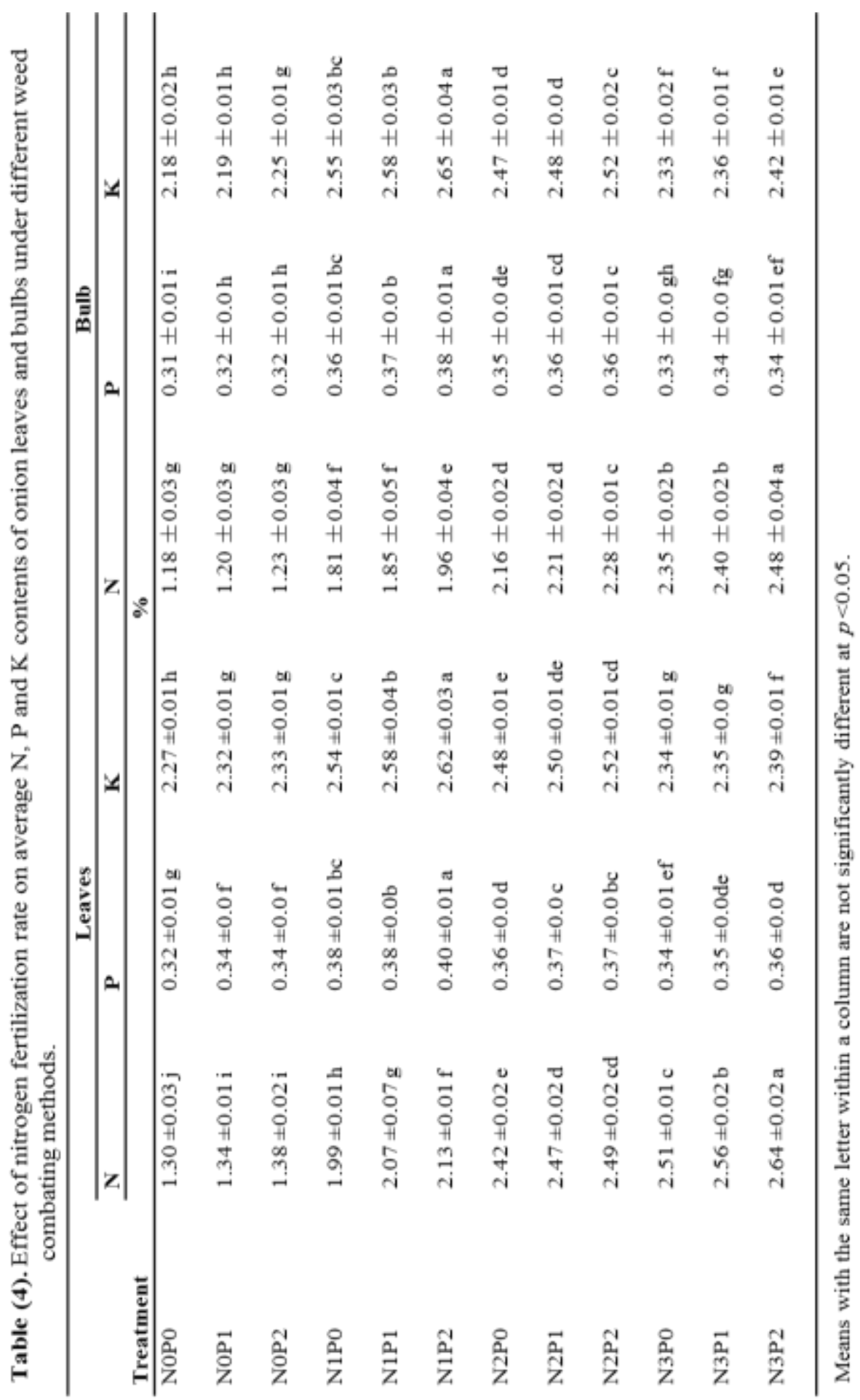

Egyptian J. Desert Res., 66, No. 1, 115-136 (2016) 
to the higher fresh weight and dry matter attained for both leaves and onion bulb (Table 3). In this study $\mathrm{P}$ and $\mathrm{K}$ fertilizers were added at constant rates for all treatments as recommended by Ministry of Agriculture-Egypt. As a result, the increased fresh and dry weight diluted the $\mathrm{P}$ and $\mathrm{K}$ contents in plant tissues. The highest $\mathrm{P}$ and $\mathrm{K}$ contents were achieved due to $\mathrm{N} 1$ treatment with average values of 0.39 and $2.58 \%$ in leaves and 0.37 and $2.59 \%$ in bulb for $\mathrm{P}$ and $\mathrm{K}$, respectively.

\section{Weeds Controlling Practices}

Data presented in fig. (2) show the average values of weeds density of both narrow and broadleaf weeds as affected by nitrogen application rates and different weeds controlling practices. Using hand weeding practice was more significantly efficient to combat weeds compared to control treatment and conventional one (using chemical herbicides). Lower weed density was observed in hand weeding practice with an average number of 2.47 weeds $/ \mathrm{m}^{2}$ followed by chemical herbicides applications of select super (clethodium 12.5\%) and bazagran (bentazon 48\%), which recorded 23.46 weeds $/ \mathrm{m}^{2}$. In addition, high weeds number was recorded for the control treatment (neither hand weeding nor chemical applications) with an average value of 56.48 weeds $/ \mathrm{m}^{2}$. The obtained results are in agreement with those of Kolhe (2001), Warade et al. (2006) and Kalhapure and Shete (2012) who found that using the hand weeding practice was sufficient for controlling weeds growth compared to the chemical methods by using herbicides.

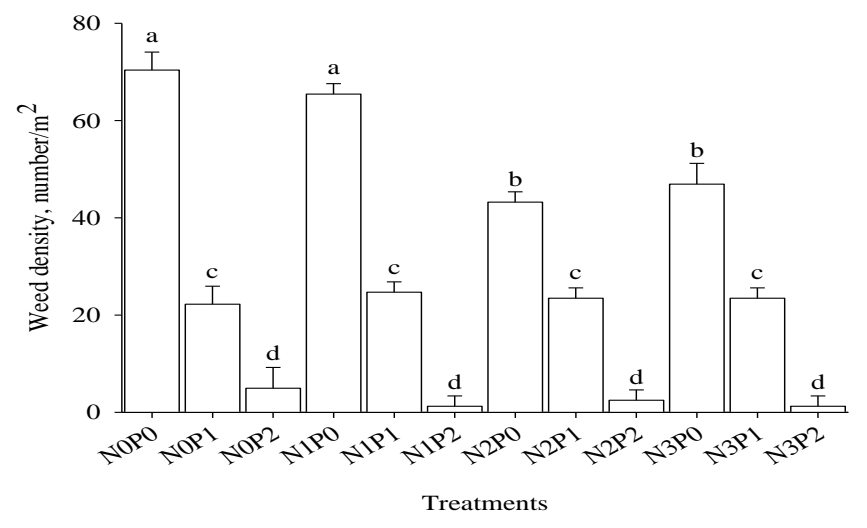

Fig. (2). Average weeds density (number $/ \mathrm{m}^{2}$ ) as affected by nitrogen fertilization rate and weeds controlling practices.

Means with the same letter within a column are not significantly different at $p<0.05$. 


\section{Residual Nitrate and Hesticides in Bulb and Human Health Aspects}

The obtained results showed that increasing the rate of applied nitrogen fertilizer led to increase $\mathrm{NO}_{3}{ }^{-}$content in onion bulb (Table 5). Over all, there were no significant difference between the concentrations of $\mathrm{NO}_{3}{ }^{-}$ after 2 and 4 months of transplanting. However, a slight reduction of $\mathrm{NO}_{3}{ }^{-}$ content occurred at the harvest stage after 6 months of transplanting. A high positive correlation was found between nitrogen rate and $\mathrm{NO}_{3}{ }^{-}$concentration in onion bulb $(p<0.01)$. The highest $\mathrm{NO}_{3}{ }^{-}$concentration was found in the $\mathrm{N} 3$ treatment after 2 and 4 months of transplanting regardless of weeds controlling practices with an average value of $144.12 \mathrm{mg} \mathrm{kg}^{-1}$ fresh weight followed by N2 and N1 treatments with average values of 111.02 and 88.58 $\mathrm{mg} \mathrm{kg}{ }^{-1}$ fresh weights, respectively. Overall, the concentration of $\mathrm{NO}_{3}{ }^{-}$in bulb didn't exceed the maximum permissible concentration of 3500-4500 $\mathrm{mg} \mathrm{kg}{ }^{-1}$ for $\mathrm{NO}_{3}^{-}$in winter crops (Europa, 2009). Similar results were attained by the previous studies; they have demonstrated that increasing the rate of applied nitrogen fertilizers led to increase $\mathrm{NO}_{3}{ }^{-}$contents in the edible parts of the growing plants. Bucklanda et al. (2013) showed that lower $\mathrm{N}$ rates led to lower residual soil $\mathrm{NO}_{3}{ }^{-}$; consequently, decreased $\mathrm{NO}_{3}{ }^{-}$contents in the growing plant. For the residual herbicides in onion bulbs, the obtained results showed that the added herbicides varied in its degradation rate (Table $5)$.

On one hand, clearly, clethodium is primarily degraded within very short time of application, and there is no residual concentrations found in the edible parts of onion plant regardless of time of sampling. Clethodim belongs to the cyclohexanedione oxime class and this class contains several numbers of herbicides that are effective against many grass weed species. Cyclohexanedione oxime has been classified in the last decades as a new class of herbicides highly effective at low dosages with good selectivity without side effects on the growing plants and the environment. Moreover, this class of herbicides is considered as environmentally friendly since they present relatively low persistence in most compartments and they are rapidly degraded under different environmental conditions (Sevilla-Mora'n et al., 2010; Sand1'n-España et al., 2013 and Monadjemi et al., 2014). Therefore, in this study spraying select super didn't cause any environmental and health risks since, there is no residual concentration was found in onion bulb. On the other hand, bentazon showed a different trend, after two months of transplanting where the levels of bentazon in onion bulbs varied from 0.2 to $0.28 \mathrm{mg} \mathrm{kg}^{-1}$ fresh weight. These levels decreased to be between 0.01 to 0.03 $\mathrm{mg} \mathrm{kg}^{-1}$ after 4 months of transplanting. Bentazon was not detected at the harvest stage after 6 months of transplanting indicating that the complete degradation of bentazon needs long time compared to clethodium. Therefore, attention should be paid when consuming onion after two months of transplanting to avoid the potential risk of the sprayed bentazon. The

Egyptian J. Desert Res., 66, No. 1, 115-136 (2016) 
previous study showed that bentazon is characterized by its high-water solubility (Wagner et al., 1996); consequently, its absorption by the growing plants is high, and the potential risk might occur.

Table (5). Average residual $\mathrm{NO}_{3}{ }^{-}$and bentazon contents $\left(\mathrm{mg} \mathrm{kg}^{-1}\right)$ in onion bulb determined at different sampling times

\begin{tabular}{|c|c|c|c|c|c|c|}
\hline \multirow{3}{*}{ Treatment } & \multicolumn{4}{|c|}{$\mathrm{NO}_{3}$} & \multicolumn{2}{|l|}{ Bentzone } \\
\hline & \multicolumn{6}{|c|}{ Sampling time, months } \\
\hline & 2 & 4 & 6 & 2 & 4 & 6 \\
\hline NOP0 & $69.61 \pm 2.3$ & $65.13 \pm 4.4$ & $54.60 \pm 4.3$ & nd & nd & nd \\
\hline NOP1 & $71.24 \pm 2.7$ & $68.55 \pm 4.5$ & $53.53 \pm 4.1$ & $0.28 \pm 0.03$ & $0.01 \pm 0.005$ & $0.01 \pm 0.008$ \\
\hline NOP2 & $69.21 \pm 1.0$ & $66.92 \pm 1.3$ & $53.71 \pm 1.8$ & nd & nd & nd \\
\hline N1P0 & $92.33 \pm 5.6$ & $92.47 \pm 2.5$ & $83.61 \pm 1.4$ & nd & nd & nd \\
\hline N1P1 & $85.21 \pm 2.3$ & $90.23 \pm 1.1$ & $84.15 \pm 5.6$ & $0.20 \pm 0.02$ & $0.01 \pm 0.007$ & nd \\
\hline $\mathrm{N} 1 \mathrm{P} 2$ & $86.68 \pm 3.1$ & $84.56 \pm 3.3$ & $\begin{array}{l}82.79 \pm 4.1 \\
103.71 \pm\end{array}$ & nd & nd & nd \\
\hline $\mathrm{N} 2 \mathrm{P} 0$ & $108.49 \pm 1.3$ & $109.69 \pm 1.7$ & $\begin{array}{l}1.8 \\
108.83 \pm\end{array}$ & nd & nd & nd \\
\hline $\mathrm{N} 2 \mathrm{P} 1$ & $110.37 \pm 1.1$ & $112.03 \pm 1.0$ & $\begin{array}{l}3.1 \\
103.95 \pm\end{array}$ & $0.24 \pm 0.02$ & $0.03 \pm 0.01$ & nd \\
\hline $\mathrm{N} 2 \mathrm{P} 2$ & $108.31 \pm 7.9$ & $117.20 \pm 2.0$ & $\begin{array}{l}3.6 \\
133.19 \pm\end{array}$ & nd & nd & nd \\
\hline N3P0 & $146.67 \pm 3.5$ & $139.21 \pm 3.8$ & $\begin{array}{l}6.2 \\
135.53 \pm\end{array}$ & nd & nd & nd \\
\hline N3P1 & $146.55 \pm 4.5$ & $140.06 \pm 2.1$ & $\begin{array}{l}4.5 \\
139.05 \pm\end{array}$ & $0.22 \pm 0.01$ & $0.03 \pm 0.01$ & nd \\
\hline N3P2 & $151.31 \pm 2.9$ & $140.94 \pm 2.7$ & 3.8 & nd & nd & nd \\
\hline $\begin{array}{l}\text { MRL, mg } \\
\mathrm{kg}^{-1}\end{array}$ & 3500 to 4500 & & & & $0.04 * *$ & \\
\hline
\end{tabular}

MRL maximum residual levels

nd not detected

*Maximum allowable concentrations of $\mathrm{NO}_{3}{ }^{-}$in winter crops (Europa, 2009).

** USEPA (1998).

Fig. ( $3 \mathrm{a}$ and $\mathrm{b}$ ) show the $\mathrm{HI}$ values of $\mathrm{NO}_{3}{ }^{-}$and bentazon calculated from onion consumption via ingestion pathway. The obtained results showed that the highest HI values were recorded for N3 treatment regardless of weeds controlling practices. In addition, the plants accumulated high $\mathrm{NO}_{3}{ }^{-}$in bulb; consequently, human are exposing high concentration of $\mathrm{NO}_{3}^{-}$as a function of nitrogen fertilizer application. The highest average $\mathrm{HI}$ values after 4 and 6 months of transplanting were $6.98 \mathrm{E}-02$ for N3 treatment; followed by $\mathrm{N} 2$ and $\mathrm{N} 1$ treatments with average $\mathrm{HI}$ values of 5.52E-02 and 
4.36E-02, respectively (Fig. 2a). Similarly, the HI values of bentazon were recorded only in the P1 treatment (using chemical herbicides) regardless of nitrogen fertilizer application rate. In addition, the levels of bentazon exceeded the maximum residual level (MRL) of 0.04 (FAO/WHO, 1995). The HI values of bentazon rose after two months of transplanting; thereafter, the HI values eliminated after 4 months to reach zero after 6 months of transplanting (Fig. 2b). A point to note that the $\mathrm{HI}$ values of $\mathrm{NO}_{3}{ }^{-}$and bentazon didn't exceed the safe level of 1 . However, attention should be paid when considering the levels of $\mathrm{NO}_{3}{ }^{-}$and bentazon in other plants consumed by human in the study location.

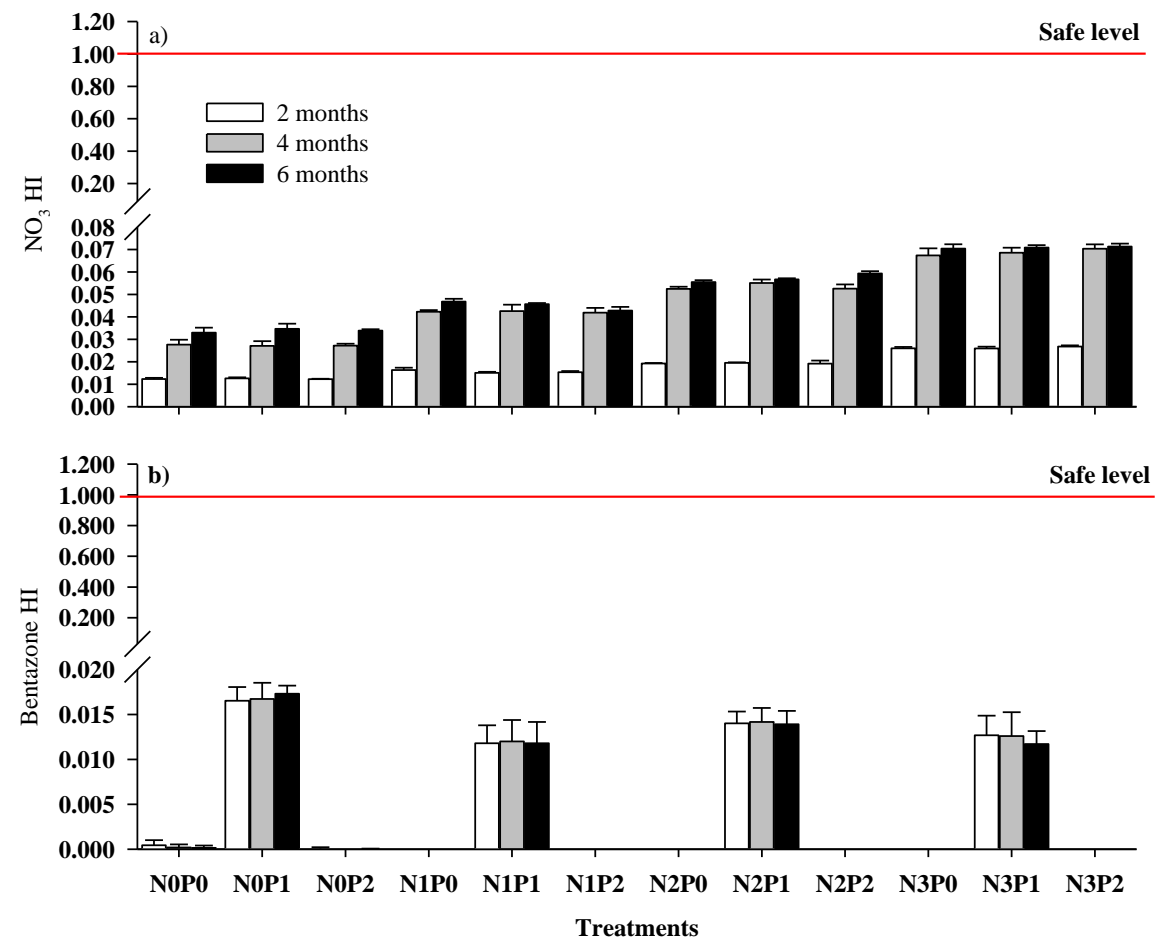

Fig. (3). HI values of nitrate (a) and bentazon (b) as affected by nitrogen fertilization rate and weeds controlling practices

\section{CONCLUSION}

According to the present investigation, it could be concluded that addition of nitrogen fertilizer plays an important role for enhancing plant growth and maximizing marketable yield. However, attention should be paid to overcome the potential contamination of groundwater with nitrate. Therefore, additional studies are needed to determine the feasibility of mineral fertilizer foliar application for enhancing plant growth and

Egyptian J. Desert Res., 66, No. 1, 115-136 (2016) 
increasing yield in the newly reclaimed soils. Furthermore, the net HI of foods is an important factor for the determination of safe food consumption subjected to high nitrogen applications and herbicides. Furthermore, clethdoium herbicide didn't pose any potential risk for human. However, bentazon accumulated in onion bulb and poses a potential risk for human in the study area.

\section{ACKNOWLEDGMENT}

The authors thank the anonymous reviewers for their valuable comments and suggestions on this study.

\section{REFERENCES}

Abdelhafez, A.A., H.H. Abbas, R.S. Abd-El-Aal, N.F. Kandil, J. Li and W. Mahmoud (2012). Environmental and health impacts of successive mineral fertilization in Egypt. Clean-Soil, Air, Water, 40 (4): 356363.

Abdelhafez, A.A. and J. Li. (2015). Environmental monitoring of heavy metal status and human health risk assessment in the agricultural soils of the Jinxi River Area, China. Human and Ecological Risk Assessment, 21 (4): 952-971.

Abdelhafez, A.A., M.H.H. Abbas and T.M.S. Attia (2015). Environmental monitoring of heavy-metals status and human health risk assessment in the soil of Sahl El-Hessania area, Egypt. Polish Journal of Environmental Studies, 24 (2): 459-467.

Akoto, O.J., J.H. Ephraim and J. Darko (2008). Heavy metals pollution in surface soils in the vicinity of abundant railway servicing workshop in Kumasi Ghana. International Journal of Environmental Research, 2: 359-364.

Albero, B., C.S. Brunte and J.L. Tadeo (2001). Multiresidue determination of pesticides in honey by matrix solid-phase dispersion and gas chromatography with electron-capture detection. Journal of AOAC International, 84 (4): 1165-1171.

Anastassiades M., S.J. Lehotay, D. Stajnbaher and F.J. Schenck (2003). Fast and easy multiresidue method employing acetonitrile extraction/partitioning and dispersive solid phase extraction for the determination of pesticide residues in produce. The Journal of AOAC International, 86 (2): 412-431.

Brady, N.C. and R.R. Weil (2008). In "Soil Colloids: Seat of Soil Chemical and Physical Acidity" (Brady N.C. and R.R. Weil eds). The Nature and Properties of Soils. Pearson Education Inc.; Upper Saddle River, NJ, USA, p. 311-358. 
Bucklanda, K., J.R. Reeve, D. Alston, C. Nischwitz, and D. Drost (2013). Effects of nitrogen fertility and crop rotation on onion growth and yield, thrips densities, Iris yellow spot virus and soil properties. Agriculture, Ecosystems and Environment, 177: 63-74.

Chen, J.Y., C.Y. Tang, Y.S. Sakura, J.J. Yu and Y. Fukushima (2005). Nitrate pollution from agriculture in different hydrogeological zones of the regional groundwater flow system in the North China Plain. Hydrogeology Journal, 13: 481-492.

Doane, T.A. and W.R. Horwa'th (2003). Spectrophotometric determination of nitrate with a single reagent. Analytical Letters, 36: 2713-2722.

Dragon, K. (2013). Groundwater nitrate pollution in the recharge zone of a regional Quaternary flow system (Wielkopolska region, Poland). Environmental Earth Sciences, 68: 2099-2109.

El-Desuki, M., R.M. Asmaa and M.H. Magda (2006). Response of onion plants to minerals and biofertilizers application. Research Journal of Agriculture and Biological Sciences, 2 (6): 292-298.

EU Scientific Committee for Food (1995). Opinion on nitrate and nitrite. Expressed on 22. September 1995. European Commission DG III, Brussels. Annex 4 to document III/56/95, CS/CNTM/NO3/20FINAL.

EUROPA (European Union Scientific for Food) (2009). Opinion on nitrate and nitrite. http:// ec.europa.eu/

FAO/WHO (1995). GEMS/Food-EURO Second Workshop on Reliable Evaluation of Low-level Contamination of Food. Geneva, World Health Organization, Report on a Workshop in the Frame of GEMS/Food-EURO, Switzerland.

FAO (Food and Agricultural Organization) (2000). Fertilizers and their use. A pocket guide for extension officers. Fourth edition. ftp://ftp.fao.org/agl/agll/docs/fertuse.pdf

Geries, L.S.M. (2013). Effect of nitrogen fertilizer and foliar spraying with humic acid on growth and yield of onion (Allium cepa L.). Egypt Journal of Applied Science, 28 (4): 204-226.

Halvorson, A.D., M. Bartolo, C.A. Reule and A. Barrada. (2006). Onion response to nitrogen fertilization under drip and furrow irrigation. National Allium Research Conference. p. 73-78, United States Department of Agriculture (USDA), Agric. Res. Service.

Halvorson, A.D., M. Bartolo, C.A. Reule and A. Barrada (2007). Nitrogen effects on onion yield under drip and furrow irrigation. Agronomy Journal, 100 (4): 1062-1069.

Halvorson, A.D., M.E. Bartolo, C.A. Reule and A. Berrada (2008). Nitrogen effects on onion yield under drip and furrow irrigation. Agronomy Journal, 100: 1062-1069.

Egyptian J. Desert Res., 66, No. 1, 115-136 (2016) 
Hassan, H.B.A., E.O. Mohamd, M.R. El-Gebaly and Y.M.M. Hessein. (2014). An analytical economic study of production and export of onion in Egypt. Nature and Science, 12 (1): 62-73.

https://cfpub.epa.gov/ncea/iris/iris_documents/documents/toxreviews/0134tr. pdf

Jones, I.R., I. Benton, B. Wolf and H.A. Mills (1991). In "Plant Analysis Handbook: Methods of Plant Analysis and Inter-Predation. MicroMacro. Publishing Inc., USA, p. 30-34.

Jones, J.B. (2001). In "Laboratory Guide for Conducting Soils Tests and Plant Analysis, CRC Press, New York.

Kalhapure, A.H. and B.H. Shete (2012). Integrated weed management in onion. Indian Journal of Weed Science, 44 (2): 88-91.

Katung, M.D., I.M. Hassbini and J.D. Olarewaju (2005). Yield and storability of onion (Allium cepa L.) as influenced by organic and inorganic fertilizers in the Sudan Savanna region of Nigeria. Nigerian Journal of Horticulture Science, 10: 82-86.

Kolhe, S.S. (2001). Integrated weed management in onion (Allium cepa L.). Indian Journal of Weed Science, 33 (1\&2): 26-29.

Lee, S.W., B.T. Lee, J.Y. Kim, K.W. Kim and J.S. Lee (2006). Human risk assessment for heavy metals and as contamination in the abandoned metal mine areas, Korea. Environmental Monitoring and Assessment, 119: 233-244.

Mann, L.K. (1952). Anatomy of the garlic bulb and factors affecting bulb development. Hilgardia, 21: 195-228.

Mensinga, T.T., G.J.A. Speijers and J. Meulenbelt (2003). Health implications of exposure to environmental nitrogenous compounds. Toxicological reviews, 22: 41-51.

Monadjemi, S., A. ter Halle and C. Richard. (2014). Accelerated dissipation of the herbicide cycloxydim on wax films in the presence of fungicide chlorothalonil and under the action of solar light. Journal of Agricultural and Food Chemistry, 62: 4846-4851.

Nasreen, S., M.M. Haque, M.A. Hossain and A.T.M Farid (2007). Nutrient uptake and yield of onion as influenced by nitrogen and sulphur fertilization. Bangladesh Journal of Agricultural Research, 32 (3): 413-420.

Nelson, D.W. and L.E. Sommers (1996). In "Total Carbon, Organic Carbon, and Organic Matter" (Page, A.L. Ed.). Methods of Soil Analysis Part 2. Agronomy. 9:. Am. Soc. of Agron., Madison, WI., p. 961-1010.

Pannala, A.S., A.R. Mani, J.P.E. Spencer, V. Skinner, K.R. Bruckdorfer, K.P. Moore and C.A. Rice-Evans (2003). The effect of dietary nitrate on salivary, plasma, and urinary nitrate metabolism in humans. Free Radical Biology and Medicine, 34: 576-584.

Ramalingam S.P., C. Chinnagounder, M. Perumal and M.A. Palanisamy (2013). Evaluation of new formulation of oxyfluorfen (23.5\% EC) 
for weed control efficacy and bulb yield in onion. American Journal of Plant Sciences, 4: 890-895.

Sandı'n-España, P., B. Sevilla-Mora'n, L. Calvo, M. Mateo-Miranda and J.L. Alonso-Prados (2013). Photochemical behavior of alloxydim herbicide in environmental waters. Structural elucidation and toxicity of degradation products. Microchemical Journal, 106: 212219.

Sangeetha, M. and P. Singaram (2007). Effect of lignite humic acid and inorganic fertilizers on growth and yield of onion. The Asian Journal of Soil Science, 2 (1): 108-110.

Sevilla-Mora'n, B., J.L. Alonso-Prados, J.M. Garci'a-Baudı'n and P. Sandi'nEspaña (2010). Indirect photodegradation of clethodim in aqueous media. By-product identification by quadrupole time-offlight mass spectrometry. Journal of Agricultural and Food Chemistry, 58: 3068-3076.

Sharifi, M., B.J. Zebarth, D.L. Burton, V. Rodd and C.A. Grant (2011). Long-term effects of semisolid beef manure application to forage grass on soil mineralizable nitrogen. Soil Science Society of America Journal, 75: 649-658.

Speijers, G.J.A. (1996). In "Nitrate, in Toxicological Evaluation of Certain Food Additives and Contaminants in Food" Edited by World Health Organization, Food Additives Series 35, Geneva, p. 325-360.

Tamme, T., M. Reinik and M. Roasto (2009). In "Nitrates and Nitrites in Vegetables: Occurrence and Health Risks" (Watson R.R. and V.R. Preedy eds.). Bioactive Foods Promoting Health: Fruits and Vegetables. Academic Press; Salt Lake City, UT, USA, p. 307-321.

USEPA (U.S. Environmental Protection Agency) (1997). In "Exposure Factors Handbook", General Factors, Volumes I and II, Chapters (14-7-12), U.S. Environmental Protection Agency (USEPA), Washington, DC.

USEPA (U.S. Environmental Protection Agency) (1998). Toxicological review of bentazon. In Support of Summary Information on the Integrated Risk Information System (IRIS). U.S. Washington, DC.

Warade, A.D., V.S. Gonge, N.D. Jogdande, P.G. Ingole and A.P. Karunakar (2006). Integrated weed management in onion. Indian Journal of Weed Science, 38: 92-95.

Wagner, S.C., R.M. Zablotowicz, L.A. Gaston, M.A. Locke and J. Kinsella. (1996). Bentazon degradation in soil: influence of tillage and history of bentazon application. Journal of Agricultural and Food Chemistry, 44: 1593-1598.

Xie, H.M. and B. Zhu. (2003). Research progress on non-point source pollution of nitrogen in agro-ecosystem. Ecology and Environment, 12: $349-352$.

Egyptian J. Desert Res., 66, No. 1, 115-136 (2016) 
Zheng, N., J. Liu, Q. Wang and Z. Liang. (2010). Health risk assessment of heavy metal exposure to street dust in the zinc smelting district, Northeast of China, Science of the Total Environment, 408: 726733.

Zhou, Y., Y. Zhang, X. Wang, J. Cui, X. Xia, K. Shi and J. Yu. (2011). Effects of nitrogen form on growth, $\mathrm{CO}_{2}$ assimilation, chlorophyll fluorescence, and photosynthetic electron allocation in cucumber and rice plants. Journal of Zhejiang University Science B, 12 (2): $126-134$.

Received: $29 / 10 / 2016$

Accepted: 25/12/2016 


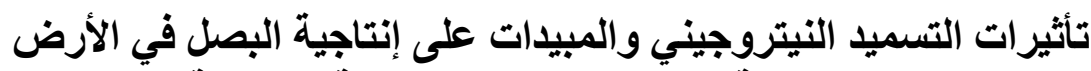 المستصلحة حليثًا ومخاطر هم الصحية المحتملة النئة}

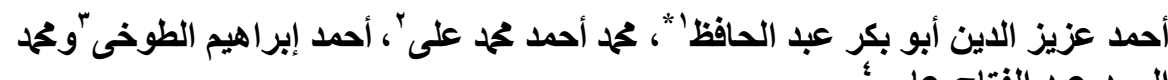

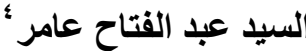

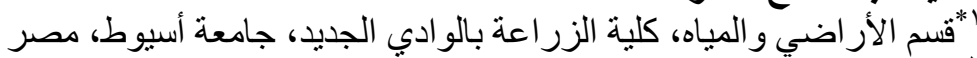

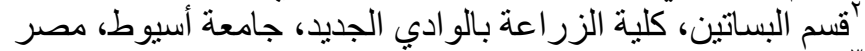

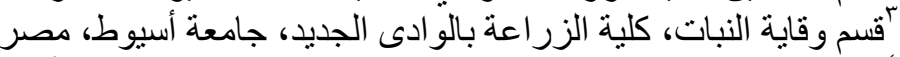

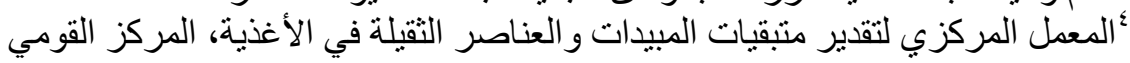
للبحوث، مصر المرئ

إضافة النيتروجين ومكافحة الحشائش من أهم الممارسات الزراعية التي يتم إجرائها

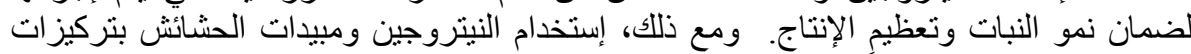

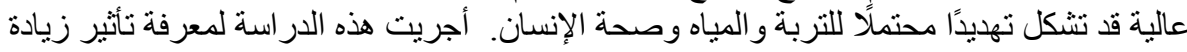

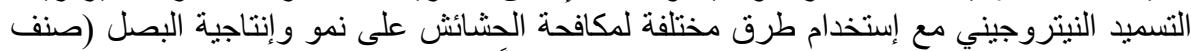

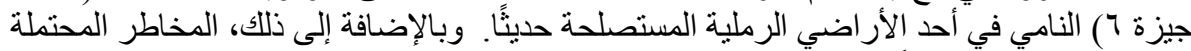

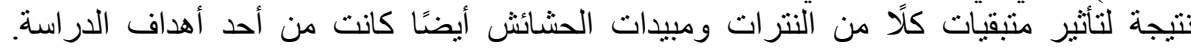

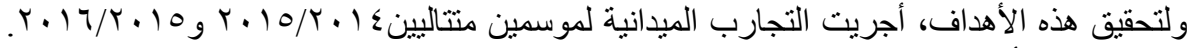

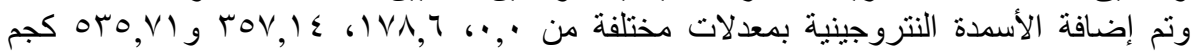

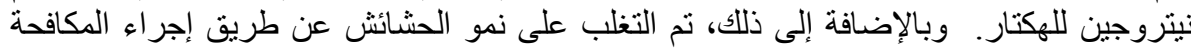

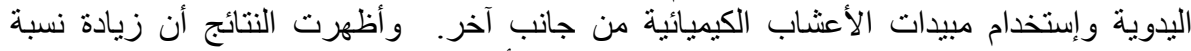

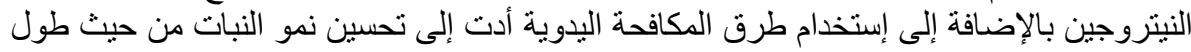

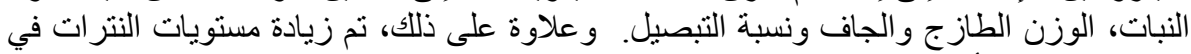

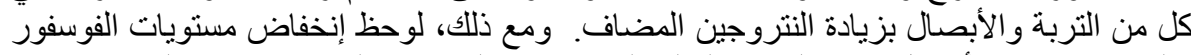

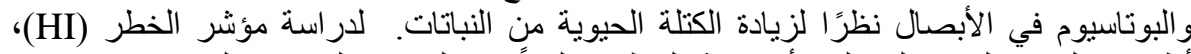

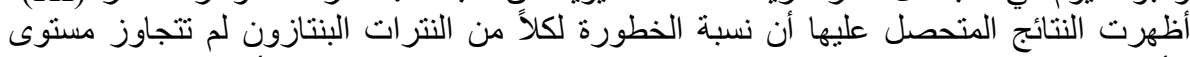

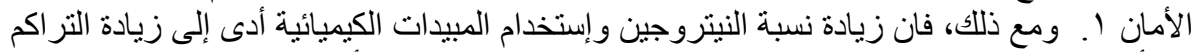

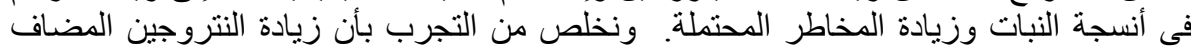

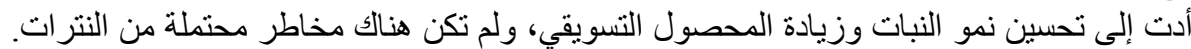

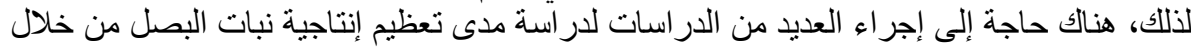

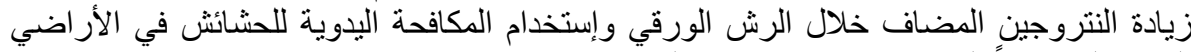

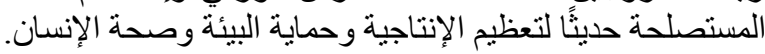

Egyptian J. Desert Res., 66, No. 1, 115-136 (2016) 